Turkish Online Journal of Qualitative Inquiry (TOJQI)

Volume 11, Issue 1, January 2020: 1-35

DOI: $10.17569 /$ tojqi.639139

Research Paper

\title{
Review of the Opinions of Vocational High School Teachers, Students, and Administrators on the Interactive Whiteboard ${ }^{1}$
}

\author{
Şükrü Aykat ${ }^{2}$, Selim Günüç ${ }^{3}$
}

\begin{abstract}
The primary aim of this study is to determine whether there was a difference in teachers' levels of interactive whiteboard usage, their self-efficacy, and opinions before and after the Use of Technology in Education Course (UTEC) in vocational high schools where FATIH project was implemented. Research participants constituted of teachers and school administrators, and students attending Telkari Vocational and Technical Anatolian High School in which interactive whiteboard installation was made within the framework of FATIH project in Midyat district of Mardin province and who attended UTEC training in the 2015-2016 academic year. In this study, a mixed research method model was used. Data were collected through scale, survey and semi-structured interview forms. Quantitative data were analyzed by mean and ttest, and qualitative data were analyzed by content analysis. In conclusion of the study, it was observed that there was no significant change in the self-efficacy of teachers using interactive whiteboard and their level of using interactive whiteboard after UTEC training. Furthermore, it was observed that teachers were unable to develop materials for the interactive whiteboard before UTEC training, and after the UTEC training, they were able to prepare materials in part. This fact has revealed that the UTEC training content was not sufficient in material development for the interactive whiteboard. The students, on the other hand, indicated that they preferred the courses used on the interactive whiteboard and asked the teachers to continue using the interactive whiteboard. Participant students indicated that interactive whiteboard failures also adversely affected the lesson. Teachers, students, and school administrators reported that use an interactive whiteboard in the course increased student success and positively affected interest and participation in the course.
\end{abstract}

Keywords: Interactive whiteboard, self-efficacy, vocational high school, FATIH Project.

\footnotetext{
${ }^{1}$ This study was conducted by the first author and produced from the master's thesis titled "Review of Opinions of Vocational High School Teachers, Students and Administrators regarding the Interactive Whiteboard before and after in-Service Training" conducted under the supervision of the second author at the Institute of Educational Sciences of Van Yüzüncü Yıl University.

2 Lecturer, Mardin Artuklu University, Midyat Vocational Schools, Computer Technologies Department, sukruaykat@gmail.com, https://orcid.org/0000-0003-1738-3696

3 Assoc.Prof.Dr., İzmir Bakırçay University, Faculty of Arts and Sciences, Psychology Department, selim.gunuc@bakircay.edu.tr, https://orcid.org/0000-0002-2278-7882
}

Received: 20.12.2018, Accepted: 25.01.2020 


\title{
Meslek Lisesi Öğretmenlerinin, Öğrencilerinin ve Okul İdarecilerinin Etkileşimli Tahta Hakkındaki Görüşlerinin İncelenmesi
}

\begin{abstract}
$\ddot{O} z$
$\mathrm{Bu}$ çalışmanın öncelikli amacı; FATİH Projesi uygulanan mesleki liselerdeki öğretmenlerin Eğitimde Teknoloji Kullanımı Kursu (ETEKUK) eğitimi öncesi ve sonrası etkileşimli tahtayı kullanma düzeylerinde, öz yeterliliklerinde ve görüşlerinde farklılık olup olmadığını belirlemektir. Araştırmanın katılımcıları, 2015-2016 eğitim öğretim yılında Mardin ili Midyat ilçesinde FATİH Projesi çerçevesinde etkileşimli tahta kurulumu yapılmış Telkari Mesleki ve Teknik Anadolu Lisesi'nde görev yapan ETEKUK eğitimine katılan öğretmenler ve okul idarecileri ile okulda eğitim gören öğrencilerden oluşmaktadır. Bu çalışmada karma yöntem modeli kullanılmıştır. Veriler ölçek, anket ve yarı yapılandırılmış görüşme formları ile toplanmıştır. Nicel veriler ortalama ve t-testi, nitel veriler ise içerik analizi ile çözümlenmiştir. Araştırma sonunda öğretmenlerin ETEKUK eğitimi sonrasında etkileşimli tahta kullanma öz yeterliliklerinde ve etkileşimli tahta kullanma düzeylerinde anlamlı bir değişimin olmadığı görülmüştür. Ayrıca öğretmenlerin ETEKUK eğitiminden önce etkileşimli tahta için materyal geliştiremedikleri ETEKUK eğitiminden sonra ise kısmen materyal hazırlayabildikleri görülmüştür. $\mathrm{Bu}$ da ETEKUK eğitim içeriğinin etkileşimli tahta için materyal geliştirmede yeterli olmadığını göstermektedir. Öğrenciler ise; etkileşimli tahta kullanılan dersleri tercih ettiklerini, öğretmenlerin etkileşimli tahtayı kullanmaya devam etmelerini istediklerini belirtmişlerdir. Etkileşimli tahta arızaları dersi olumsuz yönde etkilediğini de belirtmişlerdir. Öğretmenler, öğrenciler ve okul idarecileri derste etkileşimli tahta kullanılmasıyla; öğrenci başarısının arttığını, derse ilgi ve katılımı olumlu yönde etkilediğini belirtmişlerdir.
\end{abstract}

Anahtar Sözcükler: Etkileşimli tahta, öz yeterlilik, meslek lisesi, FATïH Projesi. 


\section{Introduction}

Recently, the use of interactive whiteboards, which is a new technology in education, has attracted the attention of educators. It can be seen that many countries invested heavily in interactive whiteboard (Holmes, 2009; Lai, 2010; Torff \& Tirotta, 2010). Interactive whiteboards are tools that resemble classic boards in form but differ from conventional wood with a touchscreen and increase user interaction (Adıgüzel, Gürbulak, \& Sarıçayır, 2011; Turel \& Demirli, 2010). The most important features of the interactive whiteboard can be listed as being able to capture images from pictures, highlighting the importance of a text through underlining it and changing its color and providing a link to a screen or website (Beauchamp \& Parkinson, 2005). The differrence between the interactive whiteboard from the use of computers and projection devices is that teachers can make any desired interventions on the whiteboard, these boards can include in disabled students to course without getting up, allow the teachers to record what is drawn on the whiteboard, and then use it or share it with their students (Kayaduman, Sarıkaya, \& Seferoğlu., 2011).

In a study conducted in 2008 in the United Kingdom, which was the first country to use the interactive whiteboard, it was determined that all primary schools and $98 \%$ of secondary schools used the interactive whiteboard (Holmes, 2009; Lai, 2010; Torff \& Tirotta, 2010). In Turkey, in 2012, interactive whiteboards began to be used in school with the Movement to Increase Opportunities and Improve Technology (FATIH). The FATIH Project is a project put forward jointly by the Ministry of National Education (MNE) and the Ministry of Transport in November 2010. The project aimed to install touch interactive whiteboards for all classes, tablets for students and multifunction printer devices. The FATIH project aims to help teachers and students spend more time in education, to benefit from technological developments in education and to use the Internet in education (Çiçekli, 2014). Besides, with the FATIH Project, it was planned to introduce students to IT (Information Technologies) at an early age and to increase the IT literacy of communities (Hörgüç, 2014).

The aspects missing from the computer-aided teaching projects carried out so far have been tried to be solved through elements such as providing the hardware and software infrastructure in the FATIH Project, providing and managing educational e-content, effective IT use in 
curriculum, in-service training of teachers, conscious, safe, manageable and measurable IT use (Ekici \& Y1lmaz, 2013).

Monitoring and examining the use of interactive whiteboards or other IT tools for the application and development of similar technological tools in education is important for the development of educational activities (Bağc1, 2013). So far, many studies have been conducted on the use, benefits, and limitations of interactive whiteboards in different learning environments. The basic idea is that interactive whiteboards can provide students and teachers with opportunities to learn convenience and impact in learning environments. It is one of the known conveniences of saving teachers time in presenting the content in courses, increasing the size of feedback to be received from the content and other students, and increasing the motivation to learn (Çelik \& Atak, 2012).

At the end of the literature review, it was found that studies were conducted on the use of interactive whiteboards, but there were no existing studies in which vocational high school teachers' levels of interactive whiteboard usage, their self-efficacy, and opinions before and after receiving "Use of Technology in Education Course" (UTEC) training under the FATIH Project. This study is significant in terms of contributing to the functioning of the FATIH Project, seeing the differences between teacher opinions before and after receiving the UTEC training, revealing the general problems of UTEC training through opinions of teachers from different branches, and in terms of providing experience and feedback to schools that have not yet been implemented with FATIH Project. In the study, the answer was sought to the question, "What are the differences between levels of using the interactive whiteboard, self-efficacy and opinions of teachers in vocational high schools with interactive whiteboard installation within the framework of FATIH Project before and after the UTEC training?". Besides, the opinions of the administrators and students regarding the interactive whiteboard were consulted. In line with these basic questions, the problems of the research were determined as follows:

1. Do the self-efficacy levels of vocational high school teachers for the interactive whiteboard before and after the UTEC training differ significantly?

2. Do vocation high school teachers' levels of using interactive whiteboards before and after UTEC training differ significantly?

3. What are the views of vocational high school teachers on the use of interactive whiteboards before and after UTEC education? 
4. What are the views of vocational high school administrators on the use of interactive whiteboards before and after UTEC training?

5. What are the opinions of the students before and after the UTEC education of vocational high school administrators and teachers?

\section{Method}

\section{Design}

Since both quantitative and qualitative data collection techniques were used in this research, the study was patterned as mixed-method. Since the research was conducted in the same time frames, a simultaneous mixed-method was used from mixed research patterns. Johnson and Turner (2003) have indicated the basic principle of mixed research as "the researcher must collect multiple data using different strategies, methods, and approaches." Creswell (2006) gives the basic proposition of the mixed approach that "using quantitative and qualitative approaches together allows us to better understand research problems than using both approaches alone."

In the study;

- Since data collection techniques with both quantitative and qualitative methods were used to learn emotions and thoughts of teachers, administrators and students before and after UTEC,

- As the findings obtained by the quantitative method are to be supported by qualitative findings,

- As it was preferred to obtain the findings that were not revealed by the quantitative method with qualitative findings, the mixed method was used.

\section{Participants}

Research participants constituted of teachers and school administrators, and students attending Telkari Vocational and Technical Anatolian High School in which interactive whiteboard installation was made within the framework of FATIH project in Midyat district of Mardin province and who attended UTEC training in the 2015-2016 academic year. 
In the qualitative research group, teachers were selected with purposeful sampling from each gender, in equal number and according to their levels of using interactive whiteboard. In this context, a total of 10 teachers, 5 of whom were men and 5 women, also 3 school administrators were interviewed with the semi-structured interview for the qualitative research. Besides, a total of 20 students, including 5 students, were selected with stratified sampling from each class level.

Research group for quantitative research constituted a total of 32 teachers including 19 men and 13 women working in the school before the UTEC training, and a total of 30 teachers including 19 men and 11 women after the UTEC training. These teachers were applied with scale and questionnaire. The reason for the decrease in the number of teachers was that two female teachers were assigned to other schools.

There was no difference in the distribution of teachers according to their gender before and after UTEC training. It was revealed that the highest participation was among teachers of vocational courses, the least participation was among teachers of the general talent and philosophy, but there was not much change in the distribution of teachers' branches. Besides, it was observed that the professional experience of the teachers included in the research was generally between 1-6 years, and their ages varied between 26 and 30 . This fact indicated that teachers were young and new in their profession.

Besides, it was observed that all teachers who participated in the study used a smartphone and owned a computer. Besides, 54 of the teachers stated that they graduated from undergraduate degrees, and 28 of them indicated that the use of technology in education in universities was moderate.

\section{Data Collection Tools}

To collect quantitative data; scales and questionnaires were applied to 32 teachers before UTEC training, and to 30 teachers after UTEC training. Scale and questionnaires were copied and distributed to everyone in the sample, requesting that the appropriate options be marked with the pen. In the information form, a personal information form was applied to determine the characteristics of teachers before and after the UTEC training. This form consisted of eleven 
questions questioning gender, branch, professional experience, age, learning status, computer and Internet connection, computer and smartphone ownership, frequency of computer and tablet use, and finally whether university/teacher education the teacher received had prepared them for the use of educational technology.

\section{Interactive Whiteboard Use Self-Proficiency Scale}

In this study, the Self-efficacy Scale for Using the Interactive Whiteboard developed by Yalçınkaya (2013) was used. Those who answered the scale indicated their opinions and assessments by selecting one of the criteria such as "Completely Disagree", "Disagree", "Neither Disagree nor Agree", “Agree”, and "Completely Disagree". Likert type scale was used in the analysis of scale questions. In the Likert type measurement method, options were rated as 1,2, 3, 4, 5-point depending on the level of importance.

\section{Interactive Whiteboard Usage Frequency Scale}

In this study, the Frequency Scale of Use of Interactive Whiteboard developed by Yalçınkaya (2013) was used. The scale was developed to determine teachers' level of using the interactive whiteboard in their lessons, how teachers used materials that were prepared related to other technological tools and subjects to which they are connected, such as the Internet and printer. The 16-item scale is in a 5-item Likert type, and the evaluation of the item in the survey was made in the form of Very Good (5), Good (4), Moderate (3), Low (2) and None (1) points.

\section{Interview Form}

In this study, semi-structured interviews were conducted with 10 teachers, 3 administrators and 20 students before and after the UTEC training to obtain data that cannot be revealed by a quantitative method. Interview questions prepared by the researchers were directed face-toface participants by taking an appointment from teachers and administrators at the appropriate time and in the Department Head of The Information Technologies Department of Telkari Vocational and Technical Anatolian High School. Interviews were recorded using a voice recorder. 


\section{The Process of Research}

In Telkari Vocational and Technical Anatolian High School, correspondence was made for the necessary permits from the school administration and the district's Directorate of National Education to apply the scale, survey and interview forms. Scale and questionnaires were applied to teachers for a week before UTEC training. Besides, interviews were conducted with teachers, students, and administrators for one month before UTEC education. One month after these studies, teachers, and administrators were given 30 hours of UTEC training in eight days by the district's national education. After teachers and administrators who received UTEC training used the interactive whiteboard for four months, the teachers were given scale and questionnaires for the second time for a week. Besides, four months after the UTEC training, interviews were made with teachers, students, and administrators for the second time for 10 days. The steps for the entire process of the research are given in Figure 1.

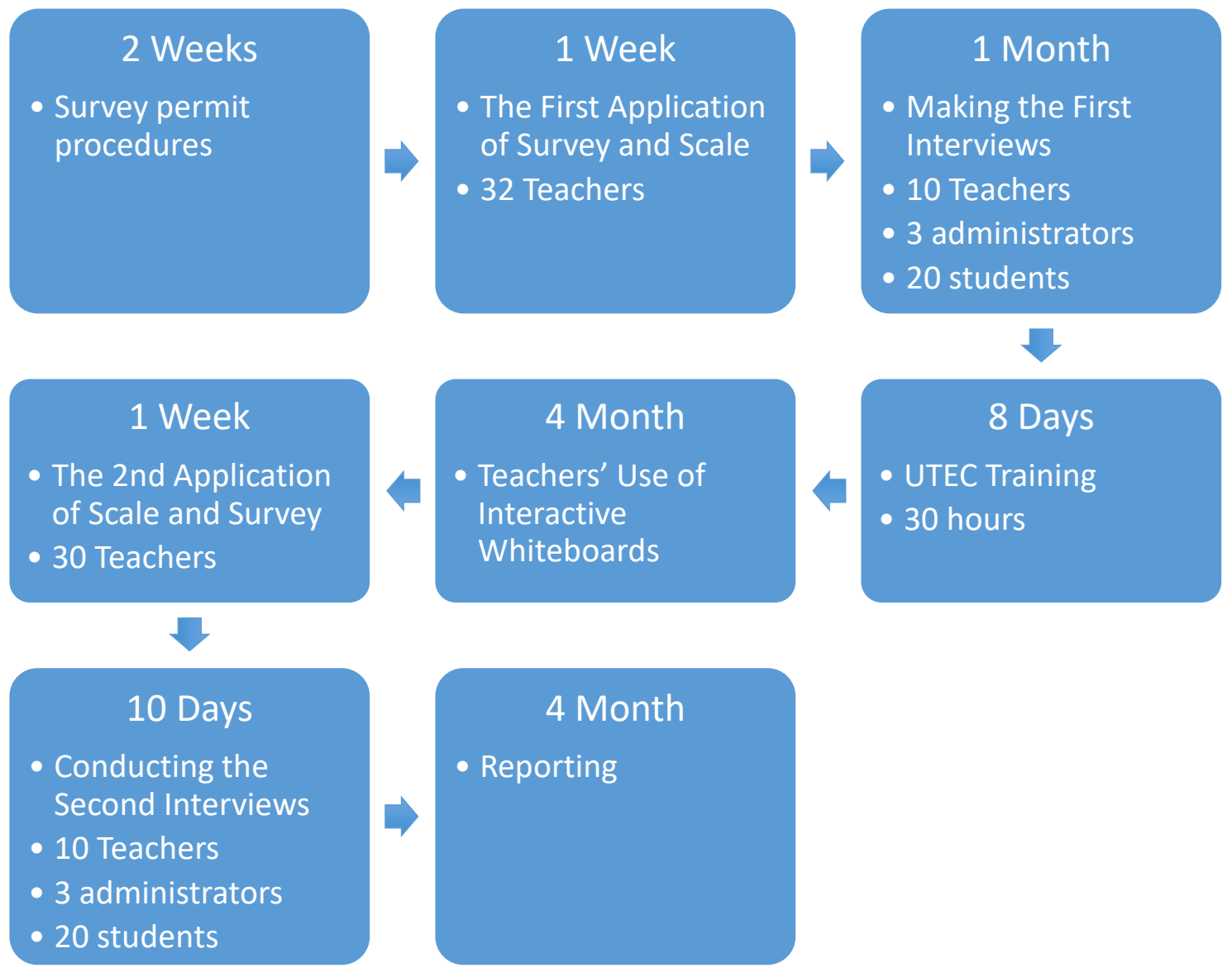

Figure 1. The Process of Research 


\section{Data Analysis}

Quantitative data obtained by scales were analyzed by SPSS 17.0 statistical software. Descriptive statistics were applied in the demographic information of the teachers in the study group (gender, age, education level, duration of service, branch), in self-efficacy to use the interactive whiteboard, and levels of use of the interactive whiteboard. On observing the normality of the distribution of scales; t-test for dependent samples, which was one of the parametric tests, was used for dependent samples to determine whether there was a difference between teachers' levels and self-efficacy of using the interactive whiteboard before and after UTEC training. The level of significance was taken as 0.05 in the analysis of data.

In the analysis of qualitative data, semi-structured interviews were conducted with the permission taken from participants, the audio recordings were then transferred to the text and checked again by the participants, the obtained interview data was analyzed by the researcher through content analysis. Common aspects of these analyses were found, and general themes and codes were created. The responses from the analysis of interview data were placed under these general themes. The frequency of expressions placed under the themes was determined and turned into tables.

\section{Findings}

In this section, the findings on teachers' self-efficacy and levels of interactive whiteboard use and their opinions on UTEC training given within the scope of FATIH Project, and findings on opinions of students and administrators were included.

\section{Examining Teachers' Self-efficacy in Using Interactive Whiteboard}

Teachers' self-efficacy scores for using interactive whiteboards before and after UTEC training are given in Table 1 . 
Table 1

Teachers' Self-efficacy Scores in Using Interactive Whiteboard

\begin{tabular}{ccccc|ccccc}
\hline \multicolumn{4}{c|}{ Before UTEC Training } & \multicolumn{5}{c}{ After UTEC Training } \\
\hline $\mathrm{n}$ & Min & Max & Range & $\overline{\mathrm{X}}$ & $\mathrm{n}$ & Min & Max & Range & $\overline{\mathrm{X}}$ \\
\hline 32 & 2.74 & 4.96 & 2.22 & 3.93 & 30 & 3.35 & 4.96 & 1.61 & 3.98 \\
\hline
\end{tabular}

When Table 1 is examined; it is observed that the value range before UTEC training was greater than the value range after UTEC training. This shows that UTEC education brings teachers' self-efficacy scores closer together. Besides, it can be seen that the vast majority of teachers give positive feedback to self-efficacy questions about using the interactive whiteboard. When the overall average of all the substances is examined, the average of $\bar{X}=3.93$ was obtained before the training, and the average of $\bar{X}=3.98$ was obtained after the training. According to this conclusion, it is seen that, although teachers generally have the self-efficacy to use interactive whiteboards in classes before UTEC training, there is an increase in the selfproficiency levels of teachers using interactive whiteboards after UTEC training. It is also revealed that teachers' self-efficacy levels for interactive whiteboard use are at the level of "Agree" and that teachers are confident in themselves.

However, as a result of the t-test, no significant difference was found between teachers' selfefficacy scores for using the interactive whiteboard before and after UTEC training $(\mathrm{t}(29)=-$ 0.137, $\mathrm{p}=0.892$ ). It can be said that UTEC education does not make any significant changes to teachers' self-efficacy status to use the interactive whiteboard. The reason for this can be attributed to the insufficient increase before and after training.

\section{Analysis of Teachers' Levels of Using Interactive Whiteboard}

Teachers' levels of using interactive whiteboards before and after UTEC training are given in Table 2. The average of each survey item is given because a survey was used to determine levels of using interactive whiteboards. 
Table 2

Teachers' State of Using Interactive Whiteboard

\begin{tabular}{|c|c|c|c|c|c|}
\hline & \multirow[t]{2}{*}{ ITEMS } & \multicolumn{2}{|c|}{$\begin{array}{l}\text { Before UTEC } \\
\text { Training }\end{array}$} & \multicolumn{2}{|c|}{$\begin{array}{l}\text { After UTEC } \\
\text { Training }\end{array}$} \\
\hline & & $\mathrm{n}$ & $\overline{\mathrm{X}}$ & $\mathrm{n}$ & $\overline{\mathrm{X}}$ \\
\hline 1 & Writing & 32 & 3.13 & 30 & 3.53 \\
\hline 2 & Saving lesson notes on the whiteboard & 32 & 3.47 & 30 & 3.83 \\
\hline 3 & $\begin{array}{l}\text { Printing and distributing course notes to students after } \\
\text { class }\end{array}$ & 32 & 2.81 & 30 & 3.27 \\
\hline 4 & $\begin{array}{l}\text { Connecting to the Internet using an interactive } \\
\text { whiteboard }\end{array}$ & 32 & 2.97 & 30 & 3.37 \\
\hline 5 & $\begin{array}{l}\text { Using slideshows on teaching topics on the interactive } \\
\text { whiteboard }\end{array}$ & 32 & 3.84 & 30 & 4.20 \\
\hline 6 & $\begin{array}{l}\text { Use other people's or your slideshows on the } \\
\text { interactive whiteboard }\end{array}$ & 32 & 3.94 & 30 & 4.27 \\
\hline 7 & $\begin{array}{l}\text { Preparing and using worksheets on interactive } \\
\text { whiteboard for lessons }\end{array}$ & 32 & 3.50 & 30 & 3.87 \\
\hline 8 & Showing movies about topics & 32 & 3.78 & 30 & 4.17 \\
\hline 9 & $\begin{array}{l}\text { Sharing course notes with students simultaneously on } \\
\text { the web }\end{array}$ & 32 & 2.72 & 30 & 2.77 \\
\hline 10 & Drawing using the background feature & 32 & 2.72 & 30 & 3.47 \\
\hline 11 & Downloading material from the Internet about topics & 32 & 3.19 & 30 & 3.53 \\
\hline 12 & Drawing geometric shapes & 32 & 2.78 & 30 & 3.67 \\
\hline 13 & Highlighting content highlights with spotlight & 32 & 2.84 & 29 & 3.72 \\
\hline & $\begin{array}{l}\text { Printing notes written on an interactive whiteboard } \\
\text { from the printer }\end{array}$ & 32 & 2.84 & 30 & 3.30 \\
\hline 15 & Using relevant audio files and materials & 32 & 3.44 & 30 & 3.90 \\
\hline \multirow[t]{2}{*}{16} & $\begin{array}{l}\text { Making changes to map, diagram, shape, and photos } \\
\text { on the subject thanks to the interactive whiteboard's } \\
\text { drawing feature }\end{array}$ & 32 & 2.94 & 30 & 3.57 \\
\hline & General $\overline{\mathrm{X}}$ & - & 2.78 & - & 3.67 \\
\hline
\end{tabular}

Examining Table 2, it is observed that the vast majority of teachers gave positive answers to questions towards levels of using interactive whiteboards. Analyzing the general mean of all items, while $\bar{X}=3.18$ average was obtained before training, $\bar{X}=3.65$ average was obtained after the training. This finding indicates that, in this research, teachers' levels of using the interactive whiteboard increased from intermediate level $(\overline{\mathrm{X}}=3.18)$ to higher level $(\overline{\mathrm{X}}=3.65)$ thanks to UTEC training. According to this finding, it can be seen that, although teachers had a general level of using interactive whiteboard in courses before UTEC training, there was an increase in their levels of using interactive whiteboard after UTEC training. 
Teachers agreed mostly on the statement of "Use other people's or your slideshows on the interactive whiteboard" in Item 6 of Table 2 before UTEC training $(\overline{\mathrm{X}}=3.94)$ and after UTEC training $(\overline{\mathrm{X}}=4.27)$.

When table 2 is further examined, teachers agreed least on the statement of "Sharing course notes with students simultaneously on the web" in Item 9 and the statement of "Drawing using the background feature" in Item $10(\overline{\mathrm{X}}=2.72)$. After UTEC training, again teachers least agreed on the statement of "Sharing course notes with students simultaneously on the web" in Item 9 $(\overline{\mathrm{X}}=2.77)$. The greatest change was achieved in the statement of "Drawing geometric shapes" in Item 12 with an average of $\overline{\mathrm{X}}^{-}=2.78$ before UTEC training and $\overline{\mathrm{X}}=3.67$ average after UTEC training.

However, as a result of the T-test, no significant difference was found between teachers' level of interactive whiteboard use before and after UTEC training $(\mathrm{t}(29)=-1.923, \mathrm{p}=0.064)$. It can be said that UTEC education did not make any significant changes to teachers' levels of using the interactive whiteboard.

\section{Teachers' Opinions on the Use of Interactive Whiteboard before and after UTEC training}

Content analysis findings of the data collected in the interviews to determine teachers' opinions on the use of interactive whiteboards before UTEC training are given. The analysis findings of the data obtained from the 15-item interview form are given in Table 3.

Table 3

Teachers' Opinions on Interactive Whiteboard before UTEC Training

\begin{tabular}{lll}
\hline Themes & Codes & $\mathrm{f}$ \\
\hline & An applied training & 5 \\
& Accompanied by an expert instructor & 2 \\
How to receive interactive & Visually & 1 \\
whiteboard training & Technical training & 1 \\
& Face-to-face training & 1 \\
\hline Interactive Whiteboard & Owning a computer, smartphone, and tablet & 7 \\
readiness & Using other technological tools in education & 6 \\
\hline
\end{tabular}


Table 3

Teachers' Opinions on Interactive Whiteboard before UTEC Training (Continued)

\begin{tabular}{lll}
\hline Themes & Codes & $\mathrm{f}$ \\
\hline \multirow{3}{*}{$\begin{array}{l}\text { Interactive Whiteboard } \\
\text { using skill }\end{array}$} & Using a computer & 6 \\
& Understanding technology & 5 \\
& Developing material & 2 \\
& Keeping up with current topics & 1 \\
\hline & Understanding technology & 5 \\
& Allowing time-saving & 3 \\
Positive Effects & Developing material & 2 \\
& Motivating with visual materials & 2 \\
& Keeping up with current topics & 1 \\
& Addressing multiple senses & 1 \\
& Maintaining class dominance & 1 \\
\hline \multirow{5}{*}{ Adverse effects } & Time losses & 2 \\
& Technical problems & 1 \\
& Making students passive & 1 \\
& Pushing the student into laziness & 1 \\
Interactive Whiteboard & Discrediting the teacher & 1 \\
\hline Total & Ease of use & 4 \\
\hline
\end{tabular}

In Table 3, teachers' views on the interactive whiteboard before UTEC training were grouped under six themes. Considering the first theme, "How to receive interactive whiteboard training", it was observed that teachers wanted to receive interactive whiteboard training in the form of an applied training. This choice was followed by "accompanied by an expert instructor", "visually", "technical training" and "face-to-face training" choices respectively. Here are a few of the teacher's opinions on this subject:

“... I'd like to take it on a technical slope. Because I don't want to ask anyone else every time. I should be able to handle it." (P6)

"I would like to receive face-to-face and hands-on one-on-one training." (P10)

Considering the second theme, "interactive whiteboard readiness"; it can be seen that teachers use computers, smartphones, and tablets, as well as other technological tools in education. 
Therefore, it can be said that teachers can use the interactive whiteboard even before receiving UTEC training. Here are a few of the teacher's opinions on this subject:

"I use smartphones, computers, tablet-style electronic devices." (P8)

"I use a smartphone as a mobile phone, I use a laptop at home. I don't use a tablet because the smartphone does the tablet's job." (P9)

Regarding the third theme, which is "the ability to use interactive whiteboards", teachers should be able to use the computer, understand technology, develop materials and follow current topics to use the interactive whiteboard. According to these findings, it can be said that teachers who can use the technology will have no trouble using the interactive whiteboard. Here are a few of the teacher's opinions on this subject:

"A teacher needs to know how to use a computer, and needs to be prepared in advance." (P5)

"A teacher needs to be somewhat competent in current technology. So he needs to use a computer. He should be able to use a tablet." (P7)

As the fourth theme of "the positive effects of interactive whiteboard"; this theme includes factors such as facilitating teaching, increasing attendance and increasing students' attention to the course. Besides, it is also seen that the interactive whiteboard has positive effects such as saving time, motivating with visual materials, addressing multiple senses and maintaining class dominance. Here are a few of the teacher's opinions on this subject:

"The interactive whiteboard allows students to participate more in the class..." (P3)

"It makes it easier for the teacher. It draws students' attention to the lesson. It saves time." (P6)

"... We think it will be much more effective for students." (P9)

"I think it's going to be positive. Because I think the interactive whiteboard will visually attract the student's attention..." (P10)

In the fifth theme, it can be seen that negative effects of interactive whiteboards are reported such as a waste of time in the course, discrediting the teacher, passively pacifying students and pushing students into laziness. Here are a few of the teacher's opinions on this subject: 
"If the teacher is incapable of using the interactive whiteboard, it may be a waste of time." (P1)

“When used constantly, the student can turn it into laziness.” (P5)

"I think there may be a glitch in the event of a malfunction. The teacher's adherence to fully interactive whiteboard can cause students to be pacified." (P8)

Considering the sixth theme, self-efficacy in interactive whiteboards, teachers reported that they can prepare materials and it is easy to use interactive whiteboards. Here are a few of the teacher's opinions on this subject:

"Yes, I think I can use it. Because I hope to use it because we use tablets and computers in everyday life." (P6)

“... I can develop materials after developing myself in the profession.” (P8)

The prominent themes according to Table 3 are shown in the diagram below.

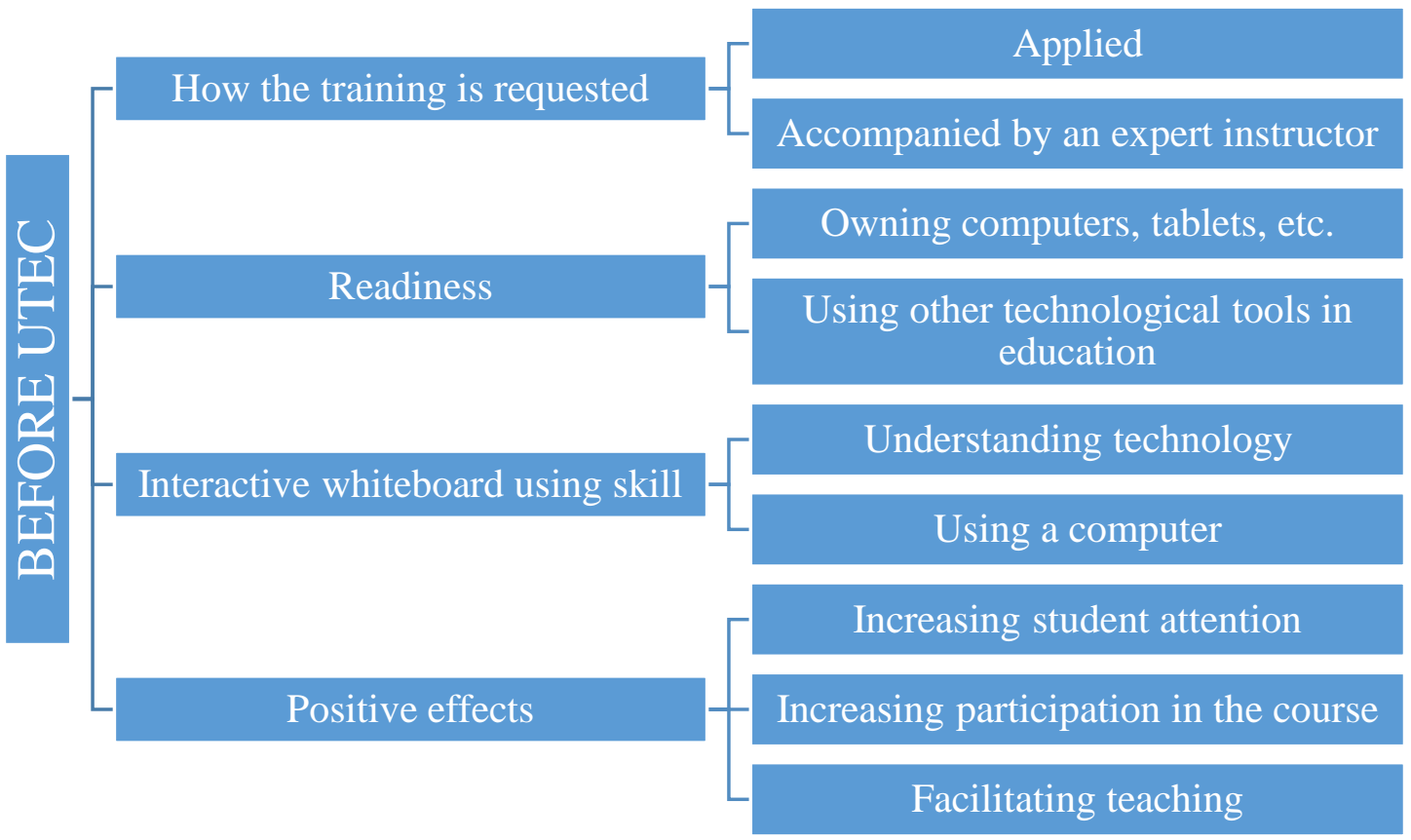

Figure 2. Teachers' Opinions on Interactive Whiteboard before UTEC Training 
Content analysis findings of the data collected in the interviews to determine teachers' opinions on the use of interactive whiteboards after UTEC training are given. The analysis findings of the data obtained from the 3-item interview form are given in Table 4.

Table 4

Teachers' Opinions on Interactive Boards after UTEC Training

\begin{tabular}{|c|c|c|}
\hline Themes & Codes & $\mathrm{f}$ \\
\hline \multirow{9}{*}{ Positive Effects } & Interest in the course has increased & 7 \\
\hline & It drew attention to the lesson. & 5 \\
\hline & It provided visualization & 3 \\
\hline & Course participation increased & 3 \\
\hline & Simplifies time management & 2 \\
\hline & Effective classroom management provided & 1 \\
\hline & Facilitated teacher's work & 1 \\
\hline & Increased success in education & 1 \\
\hline & Ensured the permanence of the information & 1 \\
\hline \multirow{4}{*}{$\begin{array}{l}\text { Frequency of interactive } \\
\text { whiteboard usage }\end{array}$} & At the beginning of the lesson & 5 \\
\hline & Continuously & 3 \\
\hline & At the end of the lesson & 2 \\
\hline & Once or twice a week & 1 \\
\hline \multirow{6}{*}{$\begin{array}{l}\text { The objective of interactive } \\
\text { whiteboard usage }\end{array}$} & Narrative & 4 \\
\hline & Watching a video & 3 \\
\hline & Reinforcement & 2 \\
\hline & For attracting attention & 2 \\
\hline & For a summary of the course & 1 \\
\hline & Solving questions & 1 \\
\hline \multirow{2}{*}{$\begin{array}{l}\text { Interactive Whiteboard self- } \\
\text { efficacy }\end{array}$} & Ease of use & 10 \\
\hline & Ability to prepare material & 7 \\
\hline Total & & 65 \\
\hline
\end{tabular}

In Table 4, teachers' views on the interactive whiteboard after UTEC training were grouped under four themes. The first theme is based on the positive effects of the interactive whiteboard; including the increase in interest and participation in the course. Besides, it is observed that there was an increase in course participation as the whiteboard added visualization to course. Besides, the interactive whiteboard is shown to facilitate time management, provide effective classroom management, facilitate the work of the teacher, increase success in education and ensure the permanence of knowledge. Here are a few of the teacher's opinions on this subject: 
"... The simplest thing is, when I let my students watch the Dardanelles documentary, I didn't think that a lot of students weren't interested. But then I did a little test on them, even two or three weeks later. They all told about two or three events to describe the event you were most impressed by the documentary. Even if they did not want to watch it, even if they talked with each other, they had it in their minds. I am sure if I were a historian and told them about the Gallipoli victory for an hour, they would not have that many events and memories left in mind. That is when I realized how effective the interactive whiteboard was." (P1)

"... I think the use of the interactive whiteboard in training is positive. It provides visuals..." (P6)

"... When it was a blackboard, there was a distraction. There was a positive development because visual things happened when there was a smartboard." (P10)

Considering the second theme, "the frequency of interactive whiteboard usage", it is observed that teachers often use the interactive whiteboard at the beginning of the lesson. This is followed by continuous use, at the end of the course and once or twice a week, respectively. Here are a few of the teacher's opinions on this subject:

"I have been using it all the time since I received the training... I mean, I use it at the beginning and the end of the course." (P3)

"When I started the lesson at the beginning, I sometimes use it to get attention..." (P6)

Considering the third theme, "objective of interactive whiteboard usage"; teachers have been found to use the interactive whiteboard to explain the subject and watch videos. These are followed by the use of the whiteboard to reinforce the subject, to draw attention, to summarize the subject of the course and to solve questions. Here are a few of the teacher's opinions on this subject:

"... I talk about the topic. I discuss it again with the videos." (P6)

"I use a summary of the course visually for children to see and to make a difference." (P7)

In the fourth theme, "the self-efficacy in interactive whiteboard", teachers reported that it was easy to use interactive whiteboard and they could prepare materials. Here are a few of the teacher's opinions on this subject: 
"Yes... It is good at attracting attention and ensuring permanence." (P6)

"I can use it... With these, I influence both the visual and auditory aspects." (P8)

"When we trained for interactive whiteboard, I prepared it partly... But of course, this work has to be continuous (these seminars). (P9)

The prominent themes according to Table 4 are shown in the diagram below.

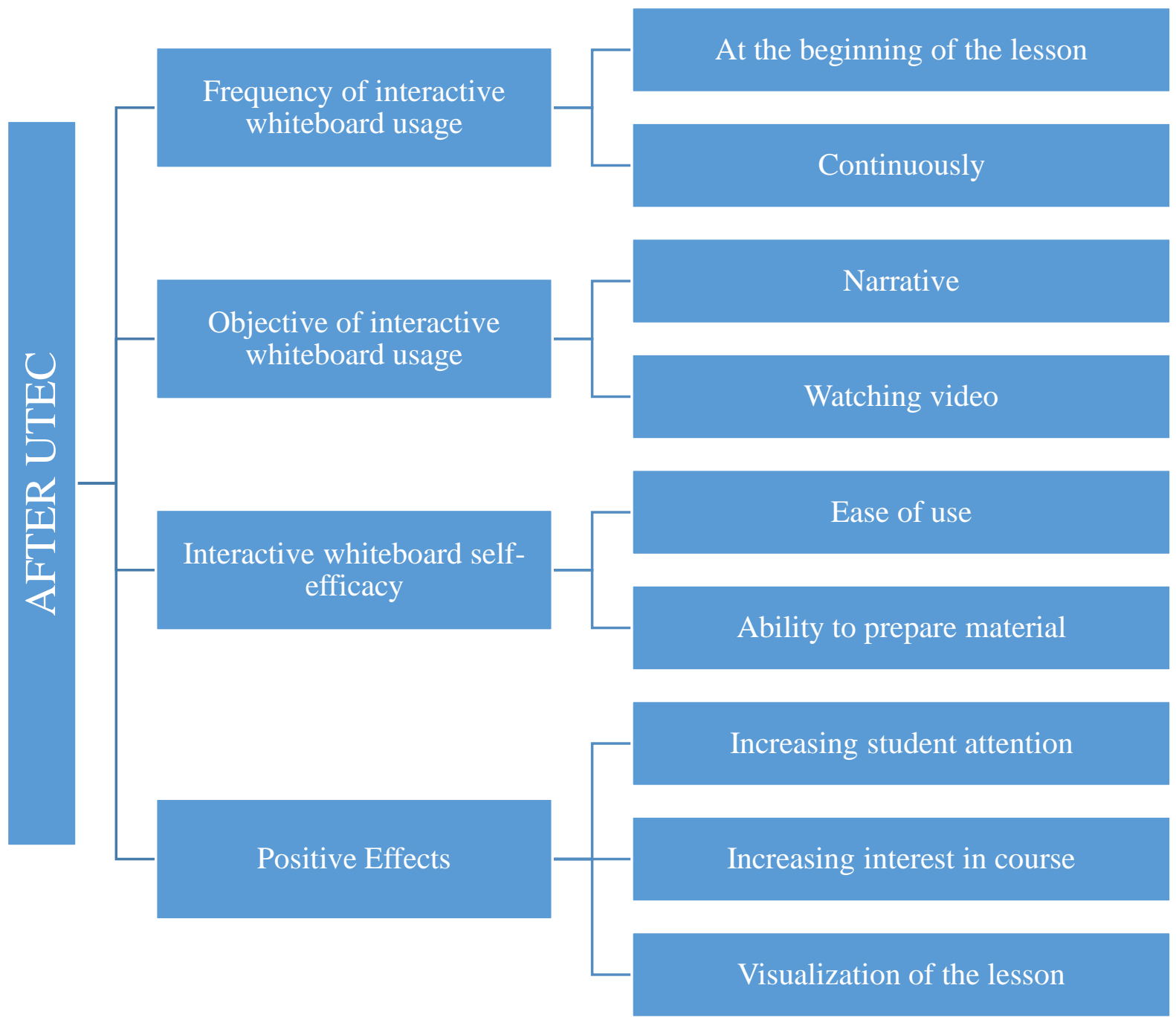

Figure 3. Teachers' Opinions on Interactive Whiteboard after UTEC Training

To determine participant teachers' opinions regarding UTEC training, the question "Did you find the interactive whiteboard training sufficient?" was asked, and the data obtained as a result of the analysis of the answers received were given in Table 5. A total of 22 opinions were taken from the 10 teachers who participated in the study. 
Table 5

Teachers' Views on UTEC Training

\begin{tabular}{lc}
\hline Opinions & $\mathrm{f}$ \\
\hline Insufficient in terms of content & 7 \\
Training time is low & 6 \\
Less number of applications & 4 \\
Sufficient in terms of content & 4 \\
The time for training is not appropriate & 1 \\
\hline Total & 22
\end{tabular}

When Table 5 is examined, it is observed that teachers found UTEC training inadequate in terms of content $(31.8 \%)$ and duration $(27.3 \%)$. These are followed by a small number of applications (18.2\%), content sufficiency (18.2\%) and inappropriate training time $(4.5 \%)$. Some of the teachers' opinions regarding this question are given below:

"No ... It would have been better if there was an education that would allow for a longer period to have such a one-on-one practice." (P3)

"Mostly I found it sufficient. Only, the training could focus more on exemplary applications. For sample applications, the time can be extended a little longer." (P8)

"I did not find it enough. I wish there was more time. I wish more practices were made." (P10)

\section{General evaluation of teachers' opinions before and after UTEC training}

Before the UTEC training, the teachers reported that they wanted to receive interactive whiteboard training in the form of hands-on training, accompanied by an expert instructor and face-to-face training. Although UTEC training was given by an expert instructor and given face-to-face, it was observed that teachers expressed generally negative opinions about education after the UTEC training. A few of these negative views indicated that UTEC education was insufficient in terms of content and duration, the number of applications was small, and the time of delivery of the training was not appropriate.

While a small number of teachers stated that they could use the interactive whiteboard before the UTEC training, it was observed that all teachers used the interactive whiteboard after the 
UTEC training. Likewise, very few teachers stated that they could prepare material before the UTEC training, while it was observed that many teachers prepared material after the UTEC training. Therefore, it was determined that teachers who did not have the self-efficacy of using interactive whiteboards used the interactive whiteboard and prepared materials with UTEC training.

It was observed that the positive opinions of the teachers regarding the interactive whiteboard were realized after the UTEC training, but their negative views were not realized after the training. It was observed that teachers' negative opinions turned into positive opinions after UTEC training.

\section{School Administrators' Opinions on Interactive Whiteboard Use before and after UTEC Training}

Content analysis findings of the data collected in the interviews to determine school administrators' opinions on the use of interactive whiteboards before UTEC training are given. The analysis findings of the data obtained from the 15-item interview form are as follows.

In interviews, three school administrators reported that they used computers, smartphones and tablet PCs in their daily lives; interactive whiteboard was a technological educational tool that facilitated teachers' work and covered educational tools. One of the opinions supporting this by a school administrator is as follows:

"The interactive whiteboard is an important training tool. It is a material that can contribute to the lesson if it is used efficiently because it is visual." (A1)

In the interview, two administrators stated that they did not receive interactive whiteboard training, and one administrator stated that he had received interactive whiteboard training. The administrator, who received interactive whiteboard training, stated that he had trouble using the interactive whiteboard because he did not use it. This administrator's opinion is given below:

"I am not comfortable with the whiteboard since I did not use it much. I have not used visual and auditory materials yet." (A2) 
Two managers who did not receive interactive whiteboard training indicated that they needed interactive whiteboard training, wanted to receive hands-on training with an expert and felt uncomfortable if they did not receive interactive whiteboard training adequately. One of the opinions of a school administrator is as follows:

"From what I have learned, I can use it. If training is not enough, I will feel uncomfortable." (A3)

In the interview, administrators stated that the success of the students would increase and the whiteboard would facilitate the teacher when it was used in interactive whiteboard training. They also stated that it should not be used in every course. Here are some of the administrators' opinions:

"I do not think the whiteboard needs to be used in every field in every class." (A2)

"I find it very useful. It will remove the book load, affect the speed of the lecture, and provide the convenience to help us in drawing issues. It will allow us to transfer some of the topics we cannot explain to the student with animations, which will make our job easier." (A3)

Administrators reported that the teacher should know how to use the computer and understand technology to use the interactive whiteboard. They also expressed an opinion that in-service training would be sufficient to be able to use the interactive whiteboard. One of the opinions of a school administrator is as follows:

"I think an in-service trained person can use the whiteboard comfortably." (A3)

In the interview, the administrators expressed the opinion that information technology devices were not guidance in the curriculum. One of the opinions of a school administrator is as follows:

"None. I find the training given within the scope of FATIH project sufficient." (A2) 
Administrators, after receiving training on the interactive whiteboard, indicated that the interactive whiteboard, which they would use in their lessons, was a useful tool for their branches. One of the opinions of a school administrator is as follows:

"I am thinking about using it. I think it will make my lesson easier whether it is drawing or animation or video." (A3)

In the interview, the administrators indicated that using visual material on the interactive whiteboard would facilitate teaching. They also stated that when they use interactive whiteboard technology, there will be a waste of time in the course and there will be disruptions in education in case of interactive whiteboard failure. One of the opinions of a school administrator is as follows:

"Because of the interactive whiteboard and tablet, students may have a situation where they come to class without books. In the event of a malfunction of your interactive whiteboard and if this malfunction is fixed late, there may be a disruption in training." (A3)

Administrators stated that the interactive whiteboard contains other technological tools, that students are ready to use the interactive whiteboard, and that the use of the interactive whiteboard will increase students' participation in the course. They also stated that, for the use of the interactive whiteboard, the district national education should provide interactive whiteboard training and that a technical staff should be present at the school.

During this meeting, the administrators stated that the EIN (Education Information Network) is a portal containing course topics and lesson videos and that they generally deem the course content sufficient but these contents were inadequate for vocational courses. They also stated that they could not develop e-content for the EIN.

Before UTEC training, school administrators generally indicated that the interactive whiteboard was a technological tool to help the teacher, that, to use the interactive whiteboard, the teacher must use a computer and understand technology, and that the interactive whiteboard was more useful since it contained other technological tools in education, and students were partially ready for interactive whiteboard technology. Also, most administrators stated that the use of interactive whiteboards in the course would increase the success of the students and 
increase participation in the course. They also stated that there was no guidance on the use of information technology devices in the curriculum and that technical staff should be present at the school.

\section{School Administrators' Opinions on Interactive Whiteboard Use after UTEC Training}

Content analysis findings of the data collected in the interviews to determine school administrators' opinions on the use of interactive whiteboards after UTEC training are given. The analysis findings of the data obtained from the 3-item interview form are as follows.

During the interview, the administrators stated that they found the UTEC training sufficient in terms of content and duration. Besides, the two administrators stated that they did not use the interactive whiteboard in their classes. Administrators do not have time to prepare course material due to workload, so it may be a reason why they do not use the interactive whiteboard. Some of the administrators' opinions on this question are given below:

"I do not use it in my class because it is a physical education class, and I do not use it because the students are mostly out, because they are in the form of games, but sometimes the whiteboard is used." (A1)

"I am trying to use it in my classes. I do not take too many classes because I am an administrator. I use it when I go to class.” (A2)

An administrator who used regularly the interactive whiteboard stated that it was easy to use an interactive whiteboard and that he could use visual and auditory materials on the interactive whiteboard, but he could not prepare the material. Also, the administrator indicated that he used the interactive whiteboard while describing and performing activities and that students were more interested in the lesson when using the interactive whiteboard. He also stated that he was able to solve some of the problems with the interactive whiteboard and that he was not afraid to lose the data by doing something wrong when using the interactive whiteboard.

Administrators stated that the interactive whiteboard provided visualization to the course and should be used in education. These views were followed by statements such as interactive whiteboard facilitates time management, it facilitates the teacher's work, it provides attention to the lesson. Besides, they also indicated that interactive whiteboards should be used in every branch. One of the administrators' opinions on this question is given below: 
"For one thing, it is very useful. As I said, he is much more effective at focusing the student's attention, putting him in class. It also makes the teacher's job easier... I would recommend it." (A3)

In general, school administrators stated that, after UTEC training, students' attention to the course increased, and interactive whiteboard should be used in education because it added visualization to the courses, and that UTEC training is sufficient in terms of content with time. Also, the administrators stated that they used the interactive whiteboard in the lecture and course activities when they needed it, but they could not develop materials.

\section{Students' Opinions on the Use of Interactive Whiteboard before and after UTEC Training}

Content analysis findings of the data collected in the interviews to determine students' opinions on the use of interactive whiteboards after UTEC training provided to teachers and school administrators are given. The analysis findings of the data obtained from the 14-item interview form are given in Table 6.

Table 6

Opinions of Students on Interactive Whiteboard before UTEC Training

\begin{tabular}{llc}
\hline Themes & Codes & $\mathrm{f}$ \\
\hline \multirow{2}{*}{ Teaching method in the course } & Interactive whiteboard & 16 \\
& Classic lesson & 4 \\
\hline \multirow{3}{*}{ Expectations from teachers } & Interactive Whiteboard should be used & 8 \\
& Interactive Whiteboard use should be learned & 4 \\
& Interactive Whiteboard should be used when needed & 2 \\
& Preparation for class should be made & 1 \\
\hline \multirow{3}{*}{ Positive Effects } & Increasing success & 16 \\
& Increasing interest & 15 \\
& Making time savings & 12 \\
& Increases participation & 11 \\
\hline \multirow{2}{*}{ Adverse effects } & Reducing success & 4 \\
& Wasting time & 3 \\
Interactive Whiteboard self- & Reducing participation & 1 \\
\hline efficacy & Easy to use & 19 \\
\hline Total & & 116 \\
\hline
\end{tabular}


In Table 6, the students' views on the interactive whiteboard were grouped under five themes before the UTEC training to be given to teachers and school administrators. When the first theme, "method of processing in the course" was taken into consideration, it was seen that the majority of students wanted the courses to be processed on the interactive whiteboard, and the few remaining students wanted that courses should be taught on the blackboard. Some of the students' opinions on this issue are given below:

"It is better to use interactive whiteboard in courses such as physics and chemistry, and the classical method in other courses." (S4)

"I prefer the interactive whiteboard because it is visual..." (S8)

In the second theme, considering students' expectations from teachers, it was observed that students wanted that teachers use interactive whiteboards, learn how to use interactive whiteboards, use them when needed, and come prepared for class. Some of the students' opinions on this issue are given below:

"Let them use the interactive whiteboard more often..." (S3)

"They need to learn interactive whiteboard programs... They need to come to class prepared." (S5)

The third theme is the positive effects of interactive whiteboard; "increasing success", "increasing interest", "saving time" and "increasing participation". Some of the students' opinions on this issue are given below:

“... The interactive whiteboard saves time.” (S2)

"Because visual materials are used, it improves performance." (S1)

“... It allows for more involvement in the class." (S15)

The fourth theme contains negative effects of interactive whiteboards such as "decreasing success", "loss of time in the course", "decreased participation". Some of the students' opinions on this issue are given below: 
"Teachers need to learn interactive whiteboard programs well. Otherwise, it is a waste of time. They need to come to class prepared." (S7)

"It does not affect interest and participation in the class." (S8)

Considering the self-efficiency, the fifth theme, students reported that interactive whiteboard use was easy. One of the students' opinions on this issue is given below:

"I find it easy because I use a computer and a smartphone." (S9)

Content analysis findings of the data collected in the interviews to determine students' opinions on the use of interactive whiteboards after UTEC training provided to teachers and school administrators are given. Analysis findings of data obtained in the 6-item interview form are given in Table 7.

Table 7

Students' Opinions on Interactive Whiteboard after UTEC Training

\begin{tabular}{llc}
\hline Themes & Codes & $\mathrm{f}$ \\
\hline \multirow{2}{*}{ Teaching method in the course } & Interactive whiteboard & 16 \\
& Classic lesson & 4 \\
\hline \multirow{2}{*}{ Positive Effects } & Increased participation & 14 \\
& Increased interest & 3 \\
\hline \multirow{2}{*}{ Adverse effects } & Interactive Whiteboard failures & 6 \\
& Abuse of interactive whiteboard & 1 \\
Interactive Whiteboard self- & Power cut & 1 \\
efficacy & Ease of use & 13 \\
\hline Total & & 58 \\
\hline
\end{tabular}

In Table 7, the students' views on the interactive whiteboard were grouped under four themes after the UTEC training to be given to teachers and school administrators When the first theme, "method of processing in the course" was taken into consideration, it was seen that the majority of students wanted the courses to be processed on the interactive whiteboard, and the few remaining students wanted that courses should be taught on the blackboard. One of the students' opinions on this issue is given below:

"I prefer courses with interactive whiteboards..." (S3) 
In the second theme, as the positive effects of the interactive whiteboard; increased participation and interest were reported. One of the students' opinions on this issue is given below:

"Interactive Whiteboard has a good effect on interest and participation in the course. Sometimes, we can go up to examples, so we participate." (S12)

The third theme shows negative effects such as the failure of interactive whiteboards, students abusing the interactive whiteboard, and power outages. Some of the students' opinions on this issue are given below:

"...For example, because it is dirty, when it is written on it, the lines can go on and on. There is no problem except for technical problems." (S5)

"Sometimes it freezes. There are no other problems." (S13)

Considering the self-efficacy in interactive whiteboard, the fourth theme, students reported that interactive whiteboard use was easy. One of the students' opinions on this issue is given below:

"It is easy, not difficult. Because it is similar to smartphones and tablets." (S3)

\section{General Evaluation of Students' Opinions regarding Interactive Whiteboard Use and UTEC training}

There were no changes in the number of students who wanted to study with both interactive whiteboard and blackboard before and after the UTEC training given to teachers and administrators. Also, before and after the UTEC training, the students expressed a positive opinion that the interactive whiteboard increased course participation.

While students reported negative opinions before UTEC training such as decreasing success, wasting time and reducing attendance in the course, they reported negative opinions after UTEC training such as interactive whiteboard failure, students' abuse of interactive whiteboard and power cuts. It can be seen that, while the negative opinions before the UTEC training were 
from academic aspects, the negative opinions after the UTEC training were from technical aspects.

Before UTEC education, almost all students stated that interactive whiteboard use would be easy, while after UTEC education, about half of the students stated that interactive whiteboard use was easy.

\section{General Assessment of Teachers, Students and School Administrators' Views on Use of Interactive Boards and UTEC Training}

Before the UTEC training, teachers, students, and school administrators reported that the use of interactive whiteboards would be easy. After the UTEC training; teachers and students used interactive whiteboards. School administrators did not use interactive whiteboards due to their workloads. Before the UTEC training, teachers and school administrators indicated that they did not develop material for interactive whiteboard. After the UTEC training; teachers reached a level that they could partially prepare the material. School administrators, on the other hand, were unable to develop materials even after the training. The content of the UTEC training needs to be improved in material development. Before UTEC training, teachers, students, and school administrators indicated that students' achievement and their participation in the course would increase with the use of interactive whiteboard in courses. After UTEC training, it was seen that these positive opinions were realized. Although teachers considered UTEC education insufficient in terms of time and content, school administrators considered the training sufficient. The reason for this contradiction is that school administrators are not objective about education and have a positive view of this training.

\section{Conclusion, Discussion and Suggestions}

\section{Conclusion and Discussion}

When the study is described in terms of demographic variables; it was determined that male teachers were included more than female teachers, and the maximum attendance was between 26-30 years old, and 1-6 years of service period teachers. Therefore, it can be concluded that the teachers participating in the study are new to their profession and young. Furthermore, after 
UTEC training, it was observed that there was an increase in the number of teachers who used the interactive whiteboard in each lesson. Besides, it was determined that vocational teachers were outnumbered in the study compared to teachers in the other branches, the majority of teachers were undergraduate graduates, they used computers and smartphones, and universities prepared these teachers to use technology at a moderate level.

When the findings on the scale and survey were examined, it was observed that, after the UTEC training, the amount of increase teachers' self-efficacy and use of interactive whiteboards in classes did not increase significantly compared to their levels before UTEC training. Both before UTEC training and after UTEC training, it was observed that teachers' self-efficacy to use the interactive whiteboard was at "Agree" level in the survey, and their level of using the interactive whiteboard was moderate. Yalçınkaya (2013), in his study, found out that there was a positive and significant relationship between teachers' self-efficacy and levels for the use of interactive whiteboards. This finding supports the results achieved in our study.

When the findings of semi-structured interview questions were examined, it was found that teachers used slideshows prepared by others or themselves, they used slideshows on teaching topics, and they showed films about topics. This is because teachers used to use computers and projection devices previously. The results of this study show parallelism with the opinions stated in the studies conducted by Altınçelik (2009) and Yalçınkaya (2013). Besides, it was found in the study that the teachers achieved a high level of increase in the level of drawing geometric shapes on the interactive whiteboard with the training of UTEC. When the field literature is examined, it is seen that teachers have objectives of saving time, drawing colorful, smooth drawings with drawing tools by using the interactive whiteboard (Smith et al., 2005).

In the study, teachers have self-sufficiencies, such as the fact that the use of interactive whiteboards is easy, and that they can prepare materials. Kurt, Günüç and Ersoy (2013), in their study, called the group "a digital immigrant" who has to follow the technology for occupational, occupational reasons, etc. Since teachers are also in the digital immigrant group, they did not have any trouble using the interactive whiteboard.

With the use of interactive whiteboards in the course, students' interest, attention and participation in the course increased. In addition to these positive benefits, interactive whiteboard should be used in training because it facilitates time management. Erduran and 
Tataroğlu (2009), as a result of their study, revealed that the use of interactive whiteboards in the course increases students' interest in the course and has a positive effect on the learning environment. Beeland (2002), on the other hand, found that using a smartboard to process the course is a tool to help teachers improve students' level of attention and their success. Furthermore, Baydash et al. (2011), as a result of their research, concluded similar results to this research reporting that interactive whiteboards can record the course, visual elements and written texts can be used effectively, animations can be shown, allowing students to direct their attention to the course, stating that the whiteboard reduces the workload of teachers.

UTEC training was given in a practical and face-to-face manner by the IT formative teacher and IT teacher. The reason for teachers' use of interactive whiteboards effectively although they consider UTEC training insufficient in terms of time and content is that teachers in this study were young and from the digital immigrant group and they achieved in closing the gap in UTEC training. The fact that teachers could not develop material at the end of the UTEC training shows that hardware and software components of the FATIH Project and the in-service training of teachers component were planned independently of each other despite the objective of FATIIH project towards increasing teaching quality of teachers. Supporting this study in a way, Koçak (2013) reported that teachers should be given necessary training at the point of material development and discovery within the scope of the FATIH Project. In this case, the number of hours allotted for material development should be increased because the UTEC training content is not sufficient to develop material for the interactive whiteboard.

School administrators have reported before UTEC training that the interactive whiteboard was a technological tool to assist the teacher and was more useful because it contained other technological tools in education. They also stated that technical staff should be present at the school because it would be a waste of time due to technical problems on the interactive whiteboard. Albayrak (2014) indicated that schools need technically equipped staff due to the idea of a waste of time due to technical glitches and the loss of time and distraction during the opening-closing of the interactive whiteboard. This research supports the present study.

In contrast to teachers' opinions, administrators stated that UTEC education was sufficient in terms of duration and content, but they were unable to prepare material for the interactive whiteboard. This also shows that administrators were not objective while evaluating UTEC training, and they considered the training positively. Besides, the majority of expectations of 
school administrators before UTEC training were not realized after UTEC training. This is because administrators are unable to use the interactive whiteboard because of their workload.

Since students are in the age of technology, they have self-efficacy such as ease of use in interactive whiteboards. Students preferred the lessons of teachers who use interactive whiteboards, so they wanted to use the interactive whiteboard in the lessons. Besides, together with using interactive whiteboards in the course; student success increased, and interest and participation in the course were positively affected. Parallel to the present work; in the study conducted by Wall et al. (2005), students indicated that it made it easier for them to learn when they used the smartboard. Teachers stated that the interactive whiteboard positively affects student attention, attention, attendance, and motivation. Bell (1998), however, stated that students are more interested in the course and motivated when the smart whiteboard is used, compared to other teaching materials.

Teachers, students, and administrators have stated that interest and participation in the course increased with the use of interactive whiteboards in the course. Kozma (1994), supporting this view, also suggested that characteristics of a certain media separated from a technological, formal or cognitive sense are its unique media features. For example, the ability of an educational game on a computer to magnify part of the screen or draw attention with color can be expressed as a media feature.

In general, within the scope of this study, it was observed that teachers had interactive whiteboard self-efficacy and usage levels. Teachers did not find UTEC training adequate and were found to be using the interactive whiteboard as a projection device. It was determined that there was not enough content in the EIN regarding vocational courses. It was determined that, although the administrators stated that they found the UTEC training sufficient, they did not use the interactive whiteboard and were unable to develop materials. This is due to their positive view of UTEC training and they were not objective on the issue. Students, on the other hand, seemed to want teachers to use interactive whiteboards in class.

Considering the limitations of the study; although many teachers, students and school administrators provided satisfactory answers to questions, some teachers, students, and school administrators gave some avoidance answers to some of the interview questions. At the same time, some teachers answered scale and survey questions by passing them out. Nevertheless, 
the data obtained from scale, survey and interview forms showed parallelism with the field literature and practical observations. The working group of the research was limited to Midyat Telkari Vocational and Technical Anatolian High School teachers. Due to the small number of teachers, interactive whiteboard self-efficacy and usage levels according to the demographic variables of teachers could not be examined. More valid results can be obtained by expanding the research into more areas.

\section{Suggestions}

\section{Recommendations for MNE, school administrators and teachers}

- Periodically, teachers may be given rearranged in-service training on the use of the interactive whiteboard.

- A technical team can be created or deployed in schools regarding interactive whiteboard and network-related technical issues.

- Teachers can be trained in developing materials for the interactive whiteboard.

- It is recommended that teachers come to class prepared.

- Hands-on topics can be processed in lessons for teachers to use interactive whiteboards.

- In in-service training and seminars for teachers; it can be emphasized that the interactive whiteboard is different from the use of a computer or a projection.

- The course curriculum may be directed towards the use of interactive whiteboards.

- Physical conditions can be improved before interactive whiteboards are installed.

\section{Recommendations for researchers:}

- As a result of this study, re-studies should be done to learn the effect of interactive whiteboard training. That is because, in general, teachers, school administrators, and students seem to have positive thoughts about the use of interactive whiteboards. It should be analyzed if there is a difference in their views in the future.

- Interactive Whiteboard usage status can be further evaluated based on the demographic variables of the teachers.

- The success of the public school and private school using interactive whiteboards can be examined in the same course.

- Larger sample groups can be examined regarding the use of interactive whiteboards. 


\section{References}

Adıgüzel, T., Gürbulak, N., \& Sarıçayır, H. (2011). Akıllı tahtalar ve öğretim uygulamalar. Mustafa Kemal University, Social Sciences Journal, 8(15), 457-471.

Albayrak, E. (2014). FATIH Projesi kapsamındaki okullarda bilişim teknolojilerinin kullanımının sınıf yönetimi açısından değerlendirilmesi. Akdeniz University, Educational Sciences Journal: Postgraduate thesis.

Altınçelik, B. (2009). İlköğretim düzeyinde öğrenmede kalıcılı̆̆ ve motivasyonu să̆laması yönünden akıllı tahtaya ilişkin öğretmen görüşleri. Sakarya University, Institute of Social Sciences: Postgraduate thesis.

Bağc1, H. (2013). FATïH Projesi çerçevesinde ortaöğretim öğrencilerinin etkileşimli tahtaya yönelik görüşlerinin incelenmesi. Okan University: Postgraduate thesis.

Baydaş, Ö., Esgice, M., Kalafat, Ö., \& Göktaş, Y. (2011), Etkileşimli tahtaların öğretim süreçlerine katkıları. 5th International Computer \& Instructional Technologies Symposium, 22-24 Eylül 2011, Firat University, Elazı̆ğ, Türkiye.

Beauchamp, G., \& Parkinson, J. (2005). Beyond the 'wow' factor: developing interactivity with the interactive whiteboard. School Science Review, 86(316), 97-103.

Beeland, W.D. (2002). Student engagement, visual learning, and technology: can interactive whiteboards help? Retrieved February 08, 2016, from http://www.sharpsav.com/wpcontent/uploads/2013/08/beeland_am.pdf.

Bell, M.A. (1998). Teachers' perceptions regarding the use of the interactive electronic whiteboard in instruction. Retrieved February 02, 2016, from http://downloads01.smarttech.com/media/sitecore/en/pdf/research_library/k-12/ teachers_perceptions_regarding_the_use_of_the_interactive_electronic_whiteboard_in _instruction.pdf.

Creswell, J.W. (2006). Understanding Mixed Methods Research, (Chapter 1). Retrieved February 10, 2016, from http://www.sagepub.com/upm-data/10981_Chapter_1.pdf.

Çelik, S., \& Atak, H. (2012). Etkileşimli tahta tutum ölçeğinin geçerlik ve güvenirlik çalışması. Anadolu Journal of Educational Sciences International, 2(2), 49-66. 
Çiçekli, E. (2014). Ortaögretim kurumlarında görev yapan ögretmenlerin FATïH Projesi kapsamında akıllı tahta kullanımına yönelik görüşleri. İstanbul Aydın University, Institute of Social Sciences: Postgraduate thesis.

Ekici, S., \& Yılmaz B. (2013). FATİH Projesi üzerine bir değerlendirme. Türk Kütüphaneciliği, 27(2), 317-339.

Erduran, A., \& Tataroğlu, B. (2009). Eğitimde akıllı tahta kullanımına ilişkin fen ve matematik öğretmen görüşlerinin incelenmesi. 9th International Educational Technology Conference (IETC2009), Ankara, Türkiye

Johnson, B., \& Turner, L.A. (2003). Data collection strategies in mixed methods research. In A. Tashakkori \& C. Teddlie (Eds.), Handbook of mixed methods in social and behavioral research (ss. 297-319). Thousand Oaks, CA: Sage.

Holmes, K. (2009). Planning to teach with digital tools: Introducing the interactive whiteboard to pre-service secondary mathematics teachers. Australasian Journal of Educational Technology, 25(3), 351-365.

Hörgüç, İ. (2014). FATİH Projesi’nin İstanbul ilinde uygulanmasına ilişkin yönetici ve ögretmenlerin görüşleri. Yıldız Teknik University, Institute of Social Sciences: Postgraduate thesis.

Kayaduman, H., Sirakaya, M., \& Seferoğlu, S.S. (2011). Eğitimde FATíH Projesinin öğretmenlerin yeterlik durumları açısından incelenmesi. Akademik Bilişim 2011, İnönü University, Malatya, Türkiye.

Koçak, Ö. (2013). FATİH Projesi kapsamındaki LCD panel etkileşimli tahta uygulamalarına yönelik öğretmen tutumlarl (Erzincan ili örneği). Atatürk University, Institute of Educational Sciences: Postgraduate thesis.

Kozma, R.B. (1994). Will media influence learning? Reframing the debate. Educational Technology Research and Development, 42(2), 7-19.

Kurt, A.A., Günüç, S., \& Ersoy, M. (2013). Dijitalleşmede son durum: dijital yerli, dijital göçmen ve dijital göçebe. Ankara University, Educational Sciences Faculty Journal, 46(1), 1-22.

Lai, H.J. (2010). Secondary school teachers'perceptions of interactive whiteboardtraining workshops: a case study from Taiwan. Educational Technology, 26(4), 511-522. 
Smith, H.J., Higgins, S., Wall, K. \& Miller, J. (2005). Interactive whiteboards: boon or bandwagon? A critical review of the literature. Journal of Computer Assisted Learning, 21(2), 91-101.

Torff, B., \& Tirotta, R. (2010). Interactive whiteboards produce small gains in elementary students'self-reported motivation in mathematics. Computers \& Education, 54, 379-383.

Türel, Y.K., \& Demirli, C. (2010). Instructional interactive whiteboard materials: Designers' perspectives. Procedia Social and Behavioral Sciences (WCLTA 2010), 9, 1437-1442.

Wall, K., Higgins, S., \& Smith, H. (2005). 'The visual helps me understand the complicated things': pupil views of teaching and learning with interactive whiteboards. British Journal of Educational Technology, 36(5), 851-867.

Yalçınkaya, Y. (2013). Ortaöğretim öğretmenlerinin etkileşimli tahta kullanımına yönelik öz yeterlikleri. Süleyman Demirel University, Institute of Science and Technology: Postgraduate thesis. 